\title{
Sheikh Mujibur Rahman and the Understanding of Democracy: A Brief Analysis
}

\author{
Ayesha Siddika $^{1 *}$, Amia Saara Khan ${ }^{2}$ \\ ${ }^{1}$ Lecturer, Department of World Religions and Culture, University of Dhaka, Nilkhet Rd, Dhaka 1000, Bangladesh \\ ${ }^{2}$ MA Candidate, Department of World Religions and Culture, University of Dhaka, Nilkhet Rd, Dhaka 1000, Bangladesh
}

DOI: $\underline{10.36347 / \text { sjahss.2021.v09i01.006 }}$

| Received: 19.12.2020 | Accepted: 22.01.2021 | Published: 25.01.2021

*Corresponding author: Ayesha Siddika

Abstract

Original Research Article

The philosophical position of Bangabandhu Sheikh Mujibur Rahman is known as Mujibvada comprising four core principles; democracy, socialism, secularism and nationalism. Throughout his political life, he propagated these principles and gave those an institutional form with the birth of Bangladesh by incorporating those principles in the constitution of Bangladesh. This article argues that Bangabandhu Sheikh Mujibur Rahman accelerated his political carrier through democratic values guided by his other philosophical spirits. His arguments in three published books resembles his cravings for establishing democracy in true essence for the emancipation of people. As the founding father of Bangladesh, his journey as political leader must be studied keeping contexts into full account. This contextual considerations allows this study to study his democracy from his writings, speeches and political actions. This study precisely argues that the original constitution of Bangladesh epitomizes the understanding of democracy of Sheikh Mujibur Rahman in institutional manner.

Keywords: Bangladesh, Bangabandhu, Mujibvada, Democracy.

Copyright @ 2021: This is an open-access article distributed under the terms of the Creative Commons Attribution license which permits unrestricted use, distribution, and reproduction in any medium for non-commercial use (NonCommercial, or CC-BY-NC) provided the original author and source are credited.

\section{INTRODUCTION}

Sheikh Mujibur Rahman, the father of the Bengali nation and the first president of Bangladesh paved the way for independent Bangladesh in 1971 after a historic struggle against Pakistan . His journey as a political leader resulting the birth of Bangladesh is characterized by bold voice and activism against suppression on the Bengalis. His philosophical ideas, ideally called Mujibvada $[1,2]$ was reflected in the original constitution of Bangladesh. Democracy had been one of the defining features of Mujib along with socialism, secularism and nationalism, which summed as the four principles of the constitution [3, 4]. Mujibs preference of democracy as a political system has been found from his writings as well as his speeches [5, 6]. He led the Bengali people and prepared them for independence in a democratic way. In this paper, his democratic view has been examined from a more academic perspective.

Different scholars have approached the definition of democracy from different perspectives. Based on the scholarly work, three points of view are found upon which the definition of democracy was given. The most widely discussed approach is from institutional perspective which focuses on the procedures. The assessment of essential features of the democracy is an interesting way to understand if democracy is being practiced properly. The democratic practice of Sheikh Mujibur Rahman has been attempted to explain with the help of "essential elements of Democracy" by the United Nations. Mujib's democratic practices, in terms of both personal view and political ideology were brought under the essential features of democracy and had been assessed. His time as a political leader including service in the office of the Prime Minister and later presidency had been brought here to understand how the democratic view had been put to exercise.

This study does not intended to explore democracy of Bangabandhu through the absolute western lens, rather this article focused on the distinct understanding of Bangabandhu on democracy which is guided by the inclusive Bengali spirit, mutual respects, people's emancipation from oppression etc. Albeit this paper draws theoretical positions from the western democracy, yet this study consciously has tried to showcase distinctiveness of the perceived and practiced democracy of Sheikh Mujib. 


\section{METHODOLOGY}

Political research can be drawn based on different methodological lens according to the demand of the research questions. Since this study seeks to explore the facets of the democracy perceived by Bangabandhu Sheikh Mujibur Rahman, therefore this study relied on mainly on the writings of Mujib and his speeches along with scholarly articles. Therefore, this study had to opt qualitative approaches including content analysis, and extensive literature review [7]. Qualitative approach helped this study in using theoretical framework using different concepts and definitions to facilitate the exploration how Sheikh Mujib conceived democracy.

\section{Definition and Theoretical Framework}

The term democracy was coined from the Greek word (demokratia) "rule of the people" which was taken from the words, demos (people) and kratos (rule) around 5th century B.C. Democracy is a form of government where laws, policies and most of activities of the state are directly or indirectly decided by the "people". Although historically this people constitute of a minor part of the total population (the free male adult in Athens), since mid-20th century all adults are included [8].

The definition of democracy varies tremendously being an ever evolving concept. The very practice of democracy also changes with time. However, broadly speaking, the concept of democracy was approached from three points of view by the scholars. The most common and widely discussed definition of democracy was set forth based on the procedure of the government [9]. In this regard, Robert Dahl's scholarly works are of great importance since they defined the essential elements of democracy: the right to vote; the right to be elected; the right of political leaders to compete for support and votes; elections that are free and fair; freedom of association; freedom of expression; alternative sources of information; and institutions that depend on votes and other expressions of preference [10]. The definition/ pronouncement/declaration of the essential elements of democracy declared by UN in 2002 is one of the most recent established work on the core element which includes: respect for human rights and fundamental freedoms, freedom of association, freedom of expression and opinion, access to power and its exercise in accordance with the rule of law, the holding of periodic free and fair elections by universal suffrage and by secret ballot as the expression of the will of the people, a pluralistic system of political parties and organizations, the separation of powers, the independence of the judiciary, transparency and accountability in public administration, free, independent and pluralistic media $[11,12]$. The definition of democracy from institutional perspective is considered as the minimum bar of democracy [13], although it is the most common discussed definition.
The central point of the second form of definition is freedom and liberty. Although Robert Dahl's emphasis had been on procedural government while defining the essential features of democracy, he also held that freedom of speech, assembly and other rights would lead to a meaningful electorate competition. Franklin Roosevelt on January 6, 1941, made an Annual Message to Congress where he emphasized on "four essential fundamental freedom" which are freedom of speech, freedom of worship, freedom from want and freedom from fear [14]. Eminent scholar Larry Diamond [12] registered political liberties, participation rights of citizens, equal justice before the law and equal rights for women as core fundamental values of democracy. Although people may not perceive the institutional procedures of democracy, these ideas of freedom and liberties can contribute to their support of democracy [15].

The third approach of the definition of democracy addresses the social dimension rather than the political point of view. Huber et al., [16] described in the article Paradox of Contemporary Democracy: Formal, Participatory and Social Dimensions, two dimensions which are: escalation of participation among social categories without systematic difference and enhancing equality in social and political development. These two dimensions were added with other four core features of formal democracy which are, regular free and fair election, universal suffrage, accountability of the state's administrative organs to the elected representatives, freedom of expression and association as well as protection against arbitrary state organ [16].

\section{RESULT DISCUSSION}

\section{Democracy perceived by Sheikh Mujibur Rahman}

Mujib had been an advocate of democracy and had dreamt of building a nation on democratic ideologies. His belief in democracy was marked by the words, "I believe in democracy, I believe in the people's right to vote".

This belief has been resonated throughout his political life. Mujib officially joined Muslim league in 1939 and had been an active member since then. But during 1943, the leaders of Muslim league divided into two groups. One group held progressive view while the other group was conservative in nature. The first group propagated for the involvement of the mass while the second group maintained that Muslim League should belong to the upper class only. Sheikh Mujibur Rahman, with his political ideal Hussain Shaheed Suhrawardy, belonged to the first group. He wrote in his auto biography, Oshomapto Attojibonee/ The Unfinished Memoirs [5], "Under the guidance of Mr. Shaheed, we wanted the middle class Bengalis to perceive Muslim league as the people's league; an organization of the mass." Muslim league, up to that point of time, belonged to the upper class of the society. 
It was the institution of the Zaminders (Landlords), Khan Bahadurs and the Nawabs. They didn't allow the common people to participate in the league, "pocketing the league (Muslim League) to themselves" [5].

Even in the darkest days of his life, when he was imprisoned from 8th May, 1966 to 22nd February, 1969 for demanding sovereignty of East Pakistan, he celebrated democracy. On his diary, he wrote on 14th July, 1966, about the French Revolution, "Even after 177 years, this day is respectfully celebrated not only by the French people, but also by the all the people around the world who believe in democracy. Sitting in this secluded chamber of the prison, I convey my respect to all those selfless revolutionists who raised the flag of democracy in the city of Paris" [6].

Mujib was the greatest among the forces that tried to resist the dictatorship of Ayub Khan, and fought persistently to reestablish democracy in East Pakistan [17]. In his famous 7 March speech he addressed the demand of democracy and constitution as well as the withdrawal of military and handing over the power to the representatives of the people, The Speech Text, 2020. Instead of accepting democratically chosen representatives, the Pakistan ruling elites brought the worst form of aggression on the people of East Pakistan. A war broke out on 26th March, 1971. After nine months of imprisonment in West Pakistan, he finally returned to Bangladesh, promised the people of Bangladesh that "there will be democracy in this Bangladesh" [18].

The importance of the rule of the mass, the very essence of democracy, was penned on by Mujib in his book Amar Dkha Noya Chin. On the way to the Peace Conference to China, the delegates of Pakistan had to pass through several countries to reach to China; and Brammadesh, the present-day Myanmar, was one of them. The country was in a state of civil war. Although Communist with the support of the Karen group tried to overthrow the government, they couldn't succeed in their aim. The reason, suggested by Mujib was that the "revolutionists" didn't get the support of the common people of the country. Mujibur Rahman maintained that, "No revolution is possible without the support from the people" [19]. This same notion was again repeated later on the book to explain the developments made by the Mao Tsu-tung government saying, "Everything is achievable with the help of the mass" [19].

\section{Elements of Democracy in the practice of Sheikh Mujibur Rahman}

The General Assembly of United Nations (UN) and the former Commission on Human Rights recommended the following characteristics as the "essential elements of democracy" in 2002: respect for human rights and fundamental freedoms, freedom of association, freedom of expression and opinion, access to power and its exercise in accordance with the rule of law, the holding of periodic free and fair elections by universal suffrage and by secret ballot as the expression of the will of the people, a pluralistic system of political parties and organizations, the separation of powers, the independence of the judiciary, transparency and accountability in public administration, free, independent and pluralistic media [11]. Many of these elements are reflected on Mujib's political life.

\section{Respect for human rights and fundamental freedoms}

The definition of human rights, provided by United Nations, are the rights entitled by every human beings irrespective of sex, religion, nationality, ethnicity, language etc. The human rights and fundamental freedoms encompasses one's right to life, liberty, employability, freedom from slavery and torture, freedom to express oneself and many other rights as announced by the Universal Declaration of Human Rights [20].

Mujib urged the world leaders to implement the Universal Declaration of Human Rights on the General Assembly held on 25th September, 1974, saying, "The responsibility is to make sure that everybody in the world can enjoy their economic, social and cultural rights conducive to the development and dignity of their personality. This right is ensured in the Universal Declaration of Human Rights. According to the Universal Declaration of Human Rights, we have to maintain our international responsibilities in such a way that every human being is assured of achieving the establishment of standard of living for the happiness and prosperity of themselves and their families" [18]

Since the formulation of Pakistan is related to a history of communal violence, it was necessary to take measures to safeguard everyone's right in the new born country. It needed to be ensured that the Muslims are not being persecuted in India or the Hindus are not deprived of their rights based on their religious affiliation in Pakistan. A farsighted leader like Suhrawardy could understand the danger both India and Pakistan would have to face in terms of tackling refugee crisis. He ordered Sheikh Mujibur Rahman to work for communal harmony. He also spoke of equal rights of the minorities in Bangladesh. Mujib started preaching the equality of every one's right. His speeches on 3rd January, 1971, 7th March, 1971, 10th January, 1972, bear the testimony of his utmost sincerity and respect for maintaining equal rights of all.

Along with religious freedom, he addresses other problems throughout his speeches. The right to employability was promised to ensure by Mujib in his speech of January 3, 1971, where he promised that he would solve unemployment problem, of 70 lack Bangalees using cottage industry and other work opportunity [21]. 


\section{Freedom of association}

International Labor Organization (ILO) defined freedom of association as the right of the employees and the employers to create any organization or connecting to it while emphasizing the importance of these organizations for a country's democratic transformation [22]. Mujib actively practiced this right throughout his political career. Even though he been an active member of the Muslim League, after the partition a culture of establishment was seen in the league which made it necessary to formulate a political party that can resist the government advancement towards an authoritarian system. So he joined Awami Muslim League in 1949 which was a democratic party. In his book, Amar Dekhe Noya Chin, where he documented his experience of visiting China, a Communist country, in 1952, he addressed the political ideology of his party, Awami League. He explained that they were an independent party who had a distinct program and a manifesto and the political ideology of the party was democracy, "We believe in democracy [19]."

\section{Freedom of expression and opinion}

The importance of the freedom of expressing oneself is upheld by Mujib in the end remark of his book "Amar Dekha Noya Chin" where he wrote, "I believe, people should have the right to demand and attain food security, but at the same time, they should have to right to preach their own opinion, otherwise human life would be as dry as a rock" [19].

The attempt of Ayub Khan's autocratic government to silence the newspaper and to repress the people of their right to express themselves has been mentioned and heavily criticized in his book, Karagarer Rojnamcha. He wrote on 5th June, 1966 "Newspapers arrived. I was alarmed that they (the Pakistani government) are trying to shut down democratic politics ... If anybody criticizes the government there will be cases against them under the proposed act ... I myself am facing five cases under article 124, section 7 (3) for making public speeches ... My fear is they are leading Pakistan toward terrorist politics. We do not believe in that politics. This path does not lead towards freedom. But those of us who want to do work for the good people through democratic politics, our space is shrinking" [6].

In his attempt to explain the democratic view of his party Awami League, he mentioned, "We believe in democracy. Silencing others with the help of law does not prevail in our party" [19]. Again, the freedom of expression not only denotes the freedom of expressing oneself, it also implied to the practice of peaceful assembly when encountered any injustice. "The citizens of every democratic country has the right to demonstrate peacefully" wrote Bangabandhu [6].
The holding of periodic free and fair elections by universal suffrage and by secret ballot as the expression of the will of the people

Holding free and fair election is one of the core characteristic of democracy. Mujib and the people of East Pakistan wanted the country to be governed in a democratic way. During 1966, Mujib presented a sixpoint demand to attain sovereignty of East Pakistan, the first of which was the demand for a federal government. It was also proposed that the government would be parliamentary in nature and selected through universal adult franchise [6]. However, when Mujib and his party, Awami League, won a landslide victory, he couldn't ascent to the office. The road of Mujib's ascension to the office has been quite turbulent. In the 1970 election, when Bangladesh was still a part of Pakistan, Mujib secured 167 of 169 seats of National assembly in East Pakistan and 288 of 300 seats of provincial assembly in East Pakistan. However, the handing over of power was deliberately delayed and soon causes unrest throughout East Pakistan. On 25th March of 1971, Mujib declared the independence of Bangladesh and urged the people of Bangladesh to resist the army occupation of Pakistan. This call for the struggle of independence was spontaneously responded by the people of Bangladesh and the war broke out.

A mandate was declared by a provisional government, widely known as Mujibnagar government, on 10th April, 1971 which reads, 'We the elected representatives of the people of Bangladesh, as honour bound by the mandate given to us by the people of Bangladesh whose will is supreme, duly constituted ourselves into a Constituent Assembly.' Ali Riaz argued that those who pronounced this declaration clearly identified the source of the legitimacy of this declaration, that is, the will of people conveyed in a democratic way. So the mandate indicated in the declaration was achieved through the 1970 election [23].

\section{Access to power and its exercise in accordance with the rule of law}

Although the right to access power is one of the essential features of democracy, Mujib was not given to chance to ascend to power even after winning the 1970 general election. Mujib after returning home on January 10, 1972 in independent Bangladesh exercised his power and promulgated the "Provisional Constitution of Bangladesh Order of 1972" which allowed the national and provincial parliament held in December 1970 and January 1971 to act as members of the Constituent Assembly of Bangladesh. Mujib officially took the oath on January 12,1971 as the prime minister of Bangladesh [24]. 


\section{A pluralistic system of political parties and organizations}

Democracy does not sustain only by depending on the state institution or civil society, it requires full incorporation of political parties in the process (European Union, 2020, Support to Political Pluralism). Every democratic system requires the participation of political parties to ensure that autocracy or dictatorship do not develop in the country. Absence of political parties can lead to the practice of authoritarianism, an example of which can be seen in the 1948 Pakistan government. After the establishment of Pakistan, the rule of Muslim League government was becoming more of an authoritarian government, and so, it was necessary to form an opposition party who would resist such authoritarian practice and would voice the demands of the people [25]. Mujib stated the necessity to form an opposition party in his book, Oshomapto Attojibonee. "There is no point in pursuing the Muslim League any longer. This party has now become the establishment. They can no longer be called a party of the people ... if we did not form an organization that could take on the role of the opposition the country would turn into a dictatorship." The plurality of political parties and other organizations, both are important to maintain democracy.

\section{The separation of powers}

The separation of power means the division of the legislative, executive, and judicial body of government will work as separate and independent bodies so that the powers are not centralized in one body [26].

Emraan Azad argued that the first ever constitution of Bangladesh was the constitutional order of $10^{\text {th }}$ April, 1971 which is known by the Proclamation of Independence and was adopted by the Mujibnagar government where Sheikh Mujibur Rahman was recognized as a in-absentia president of Bangladesh. This legislation remain in effect till the declaration of Provisional Constitution (Bangladesh's First Constitution, 2018, April, 10 ) https://www.thedailystar.net/law-our-

rights/bangladeshs-first-constitution-1560727. In this Proclamation, we see the idea of separation where the representatives divided state authorities and power among different organs of the state. Every possible effort was made to recognize the international law and especially UN Charter through this proclamation.

This separation of power was inculcated in the Constitution Bill which was enacted on $4^{\text {th }}$ November and came in effect on $16^{\text {th }}$ December, 1972, which stands as part 2 of the fundamental principles of state policy, "The State shall ensure the separation of the judiciary from the executive organs of the State" [27].

\section{The independence of the judiciary}

Although the constitution of Bangladesh enacted in 1972 promulgated the separation of power, Mujib advised for the Fourth Amendment which ran the risk of scraping the independence of judiciary. It was proposed that the power of appointing the judges by the president except that of the Supreme Court and removal of the Chief justice who could be removed by thirdfourth majority of the member of the parliament [28]. Again BAKSAL was a turnover to a presidential form of government where the power will be vested to the office of president.

\section{Transparency and accountability in public administration:}

This element of democracy is crucial to democracy to ensure that representatives of people do not stray to the path of corruption. After the victory of 1970 general election, he addressed the public where he called out the West Pakistan ruling elites and claimed accountability for the taxes paid by the East Pakistanis. East Pakistan had a long history of being deprived of their economic rights and lacked political representation. In the speech of January 3, 1971, he said, "We still give refugee taxes. Seven lack refugees came from Asam, West Bengal, Kuch Bihar and Calcutta. But no money was spent on them. We demand the money back so that we can build homes for them" [21].

\section{Free, independent and pluralistic media}

Mujib's support for free and independent media is reflected mostly in his book, "Karagarer Rojnamcha" which bears the daily account of his imprisoned life during the autocracy of Field Marshall Ayub Khan. He criticized the government's attempt to control media throughout the autocratic regime. On 4th June, 1966, he wrote, "After seeing the news of the 7th June protest, it seems like the government gave order of not printing any news related to it..... This is the freedom of newspaper! We are ashamed! The world probably laughs at this freedom of media of ours!" [6]. Again it was mentioned 5th June, 1966, "The newspaper arrived.... Pakistan News prints some kind of news nowadays. They are neither the spokesman of the Western Industrialist like Morning News nor blind supporters of the government.....A newspaper can differ in their stand/opinion, but why wouldn't newspapers print news? [5].

\section{ANALYSIS AND CONCLUSION}

Mujib had been seen as an embodiment of democratic practice in his political life and democracy was a core part of his philosophy. The very basis of the demands and policies he advised like the famous sixpoint demand and the demand of naming East Pakistan, Bangladesh was based on the democratic ideals. His writings as well as speeches bear the testimony of his deep respect for this political system. Democracy is also incorporated as one of the four fundamental principles 
of democracy. However, Sheikh Mujib was criticized on the creation of BAKSAL and the Fourth Amendment of the constitution. Bangladesh Krishak Sramik Awami League was established by Sheikh Mujibur Rahman as a inclusive political party merging all pro-Bangladesh parties limiting multi party politics. It is argued in the contemporary derailed social and political situations was responsible for disavowing multi-party democracy [29]. Mujib's opinion given on 1975 about BAKSAL has been documented on Sheikh Mujib: Triumph and Tragedy, "What an irony of fate that it is I, who for my entire life struggled for democracy and many years in prison for it, should now have to create a one-party...I don't want this. I was forced to do this. Pro-Pakistan Parties, armed followers of the JSD, Sarbahara Party and others are out to destroy the normal political life and administration of our government...This one-party arrangement is purely political. Once I save the country from counter revolution I'll restore multi-party democracy" [30]. The way Mujib saw BAKSAL was described by Sayed Badrul Ehan in the article, Lifting the long silence on Baksal, where he wrote about the anarchy created by both right and left wing extremists and the extreme level of corruption [31]. The current Prime Minister Sheikh Hasina, daughter of Sheikh Mujibur Rahman addressed this issue on November 26, 2020 , in the general discussion of parliament and opined the idea of BAKSAL was widely misinterpreted. In her speech she also mentioned that although Bangabandhu was criticized on the ground that he wanted to establish one party rule, the programs were declared for the second revolution with a view to implement socio-economic development uniting all classes of people, The Daily Star, 2020 [32]. This study also makes a normative claim that albeit Bangabandhu explicitly did not want to enact a one party system in the later days of his presidency, yet he was compelled in doing so for the given socio-political unrests. This was certainly a temporary political solution from a thinking that if political chaos would be decreased along with the tightening the grip of the antiBangladesh conspirators, reopening of multi-party democracy was a matter of time only. Neither the fourth amendment nor the creation of inclusive party politics shortens the heights of Sheikh Mujib as a democratic leader.

In this study we explicitly argue that the vision and mission of Sheikh Mujibur Rahman was the emancipation of the Bengalis through the establishment of golden Bengal; and obviously democracy was a spirit envisioned by him which could chase the dream of the millions.

Sheikh Mujibur Rahman is the most recognized and beloved leader of the people of Bangladesh and widely known for his remarkable leadership which lead to the Bengalis to the path of liberation. His philosophy was formulated with the concept of democracy, secularism, socialism and nationalism. In his political life he is seen to work for the cause of the rights and liberties of people as well as for their political and economic freedom. The six-point demand of the 1966 which lead to the way of liberation, is a fine example of laying out the democratic demands. He played a significant role in including these concepts in the Constitution of Bangladesh. Mujib had always propagated the importance of democracy and practiced it in his political life. Mujib ascended to the office of prime minister at a time when Bangladesh was in her most vulnerable state. In the post-war Bangladesh, the socio-economic conditions were exhausting and the administrative organs were dilapidated. After taking to the office, he stated working on the implementation of the four principles of the constitution. However, his democratic view came under heavy criticism for enacting Fourth Amendment and implementing BAKSAL during 1975. BALSAL being a one party rule was deemed as an undemocratic practice. But we argue that BAKSAL was made as contemporary political solution. BAKSAL remained to be a complicated issue which needs to be approached by both academics and historians to reconstruct the contemporary political condition to analyse how anti-Bangladesh force compelled Bangabandhu to implement BAKSAL.

Funding Body: This study was conducted with the research grant from the UGC, Bangladesh through the University of Dhaka under the project titled: Secular philosophy of Sheikh Mujibur Rahman.

\section{REFERENCES}

1. Anisuzzaman, (2015), Communalism and Secularism, BPL, Dhaka.

2. Riaz A. Inconvenient Truths about Bangladesh Politics. Prothoma Publications, Dhaka. 2012.

3. Islam, MD. (2020). Understanding secularisation as indicating the process of the separation of the political and religious. The Arts Faculty Journal. 10(14-15). Pp. 127-139.

4. Islam, MD. (2021). Religious Freedom for the religious minorities in Bangladesh: A critical analysis of the insertion of state religion in the constitution. OSF Preprint. (forthcoming book chapter).

5. Rahman SM. Oshomapto Attojibonee (The Unfinished Memoirs). Dhaka: University Press Limited. 2012.

6. Rahman SM. Karagarer Rojnamcha (Prison Diaries). Dhaka: Bangla Academy. 2017.

7. Halperin S, Heath O. Political Research: Methods and Practical Skills. 2016.

8. Dahl RA. Democracy. Britannica. 1998, July 20. Retrieved on 10 November 2020 from https://www.britannica.com/topic/democracy

9. Collier D, Levitsky S. Democracy with adjectives: Conceptual innovation in comparative research, World Politics. 1997. 
10. Dahl RA. Polyarchy: Participation and Opposition. New Haven: Yale University Press. $257 \mathrm{p}$.

11. United Nations. Democracy. 2020. Retrieved 18 December 2020, from https://www.un.org/en/sections/issuesdepth/democracy/index.html

12. Diamond L. Developing Democracy Towards Consolidation. Baltimore: John Hopkins University Press. 1999.

13. Dalton, C. M. (2007). The bully down the hall. Business Horizons, 50(2), 89-91.

14. Roosevelt FD. ed., The Public Papers and Addresses of Franklin D. Roosevelt, vol. 9, War and Aid to Democracies, (New York: The Macmillan Company, 1940, 663-672. Retrieved from https://www.ruhrunibochum.de/gna/Quellensammlung/09/09_fdro oseveltfourfreedomsspeech_1941.htm

15. Diamond L, Plattner M. Ed. How People View Democracy. Baltimore: John Hopkins University Press. 2009. Retrieved from https://books.google.com.bd/books?id=jcq7aaEu TCUC\&pg=PA3\&lpg=PA3\&dq=political+liberti es,+participation+rights+of+citizens,+equal+justi ce+before+the+law,+and+equal+rights+for+wom en $\&$ source $=$ bl\&ots $=r Y Q c 1 F W q 2 v \& s i g=A C f U 3$ U2cxdFYCIeuswvBbX_S68-

M0b5Jhg\&hl=en\&sa=X\&ved=2ahUKEwiJn8TR oabuAhUAgtgFHdHyChAQ6AEwAnoECAEQA $\mathrm{g} \# \mathrm{v}=$ onepage $\& \mathrm{q}=$ political $\% 20$ liberties $\% 2 \mathrm{C} \% 20 \mathrm{p}$ articipation $\% 20$ rights $\% 20$ of $\% 20$ citizens $\% 2 \mathrm{C} \% 2$ 0equal $\% 20$ justice $\% 20$ before $\% 20$ the $\% 20$ law $\% 2 \mathrm{C}$ $\% 20$ and $\% 20$ equal $\% 20$ rights $\% 20$ for $\% 20$ women\& $\mathrm{f}=$ false

16. Huber E, Rueschemyer D, Stephens J. The paradoxes of contemporary democracy: Formal, participatory and social democracy, Comparative Politics. 1997.

17. Maksud AS. The Nationalist That Mujib Was. The Daily Star. 2009, August $14^{\text {th }}$. https://www.thedailystar.net/news-detail-101470

18. Askari R. Bangabandhu's historic 1974 UN speech. The Independent. 2020, September 24. Retrieved from http://www.theindependentbd.com/post/253673

19. Rahman SM. Amar Dekha Noya Chin. Dhaka: Bangla Academy. 2020.

20. United Nations. (2020). Human Rights. Retrieved 20 December 2020, from https://www.un.org/en/sections/issuesdepth/human- rights/\#: :text=Human\%20rights\%20include\%20 the $\% 20$ right, and $\% 20$ education $\% 2 \mathrm{C} \% 20$ and $\% 20$ many\%20more

21. Speeches: 100 Years of Mujib. (2020). Retrieved 22 December 2020 from https://mujib100.gov.bd/pages/mujib/speeches.ht $\mathrm{ml}$

22. International Labor Organization. (2020). Freedom of Association. Retrieved on 18 December $2020 \quad$ from https://www.ilo.org/global/topics/freedom-ofassociation-and-the-right-to-collectivebargaining/lang--en/index.htm

23. Riaz, A. (2020, December 16). Democracy: The journey that has taken a wrong turn. The Daily Star. Victory Day Special issue, p.7.

24. Samad, S. (2020, January 19). Mujib's Challenge was the Road to Democracy. Retrieved from https://www.dhakatribune.com/opinion/oped/2020/03/17/mujib-s-challenge-was-the-roadto-democracy

25. Jahan R. The political philosophy of Bangabandhu. Dhaka Tribune. 2019, June 10. Retrieved 28 November 2020 from https://cpd.org.bd/the-political-philosophy-ofbangabandhu-dr-rounaq-jahan/

26. Separation of power. (2020). Britannica. https://www.britannica.com/topic/separation-ofpowers

27. Constitution of People's republic Bangladesh. (2019). Retrieved from http://bdlaws.minlaw.gov.bd/act-367/section24570.html

28. Chowdhury AM. The Second Revolution. 2020, October 24. Retrieved from https://www.dailysun.com/printversion/details/513629/The-

Second-Revolution

29. Ahmed M. Bela-Obela: Bangladesh 1972-1975. Dhaka, Batighar. 2020.

30. Karim SA. Sheikh Mujib: Triumph and Tragedy. Dhaka: The University Press. 2005.

31. Ehsan SB. Lifting the long silence on Baksal. 2020, January 29. Retrieved from https://www.dhakatribune.com/opinion/oped/2020/01/29/lifting-the-long-silence-on-baksal

32. BAKSAL was Formed to Unite the Nation: PM at special JS session. (2020, November, 2020). The Daily Star. Retrieved from https://www.thedailystar.net/country/news/baksal -was-formed-unite-the-nation-pm-special-jssession-1995605. 